\title{
Study on Solidification Shell Thickness of Continuous Casting Billet
}

\author{
Li Huicheng*, Xu Bijing, Ren Zhenhai and Zhu Fuqiang
}

Zenith Steel Group Company Limited, Changzhou Jiangsu 213011, China

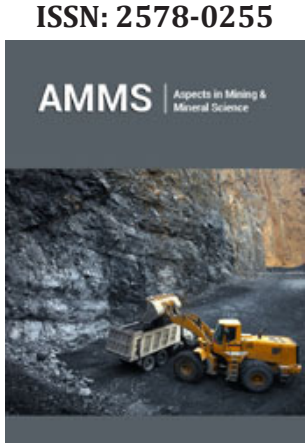

*Corresponding author: Li Huicheng, Zenith Steel Group Company Limited, Changzhou Jiangsu 213011, China

Submission: 淟 February 11, 2021

Published: 監 March 01, 2021

Volume 6 - Issue 2

How to cite this article: Li Huicheng, Xu Bijing, Ren Zhenhai and Zhu Fuqiang. Study on Solidification Shell Thickness of Continuous Casting Billet. Aspects Min Miner Sci. 6(2). AMMS. 000634. 2021.

DOI: 10.31031/AMMS.2021.06.000634

Copyright@ Li Huicheng, This article is distributed under the terms of the Creative Commons Attribution 4.0 International License, which permits unrestricted use and redistribution provided that the original author and source are credited.

\section{Opinion}

The $220 \mathrm{~mm} \times 260 \mathrm{~mm}$ section continuous casting billet in the company of electric furnace was the research object in this paper. At the same time, according to the theory of solidification shell thickness calculation formula combining design measure specific location of the solidification shell thickness test. It can provide reliable basis for the subsequent F-EMS optimization and basic data support for the transformation and improvement of solidification structure of billet under soft reduction. Accurately determine the casting billet specific location of the solidified shell thickness and solidification coefficient for optimal setting at the end of the end of the electromagnetic stirring (F-EMS) and light pressure parameters, maximum play F-EMS and gently press down at the end of the effect of center segregation and osteoporosis has important reference meaning, at the same time, according to the thickness of the solidified shell can be used to analyze cause of forming defect, the rationality of the secondary cooling water distribution system, and forecast the potential of improving continuous casting speed, etc [1-4]. The action areas of the final stirring electromagnetic stirring are the liquid core and the paste area of the continuous casting billet. By adjusting the electromagnetic parameters of the final stirring, a clear white bright band can be produced in the cross section of the billet, according to which the thickness of solidified billet shell at the final stirring position can be judged [5-7]. Using 45 steel as the research object, the superheat was controlled at about 25 ${ }^{\circ} \mathrm{C}$, the drawing speed was $1.05 \mathrm{~m} / \mathrm{min}$, the secondary cooling water ratio was $0.25 \mathrm{~L} / \mathrm{kg}$, the final stirring position was $10.15 \mathrm{~m}$ away from the moon surface, the electromagnetic stirring intensity at the end was adjusted to make the solidification structure produce white bright band, and the shell thickness of solidification billet was determined according to the position of the white bright band on the cross section of the casting billet (Figure 1). At the same time, the comprehensive solidification coefficient $\mathrm{K}$ is calculated according to the calculation formula of solidified shell thickness in solidification theory.

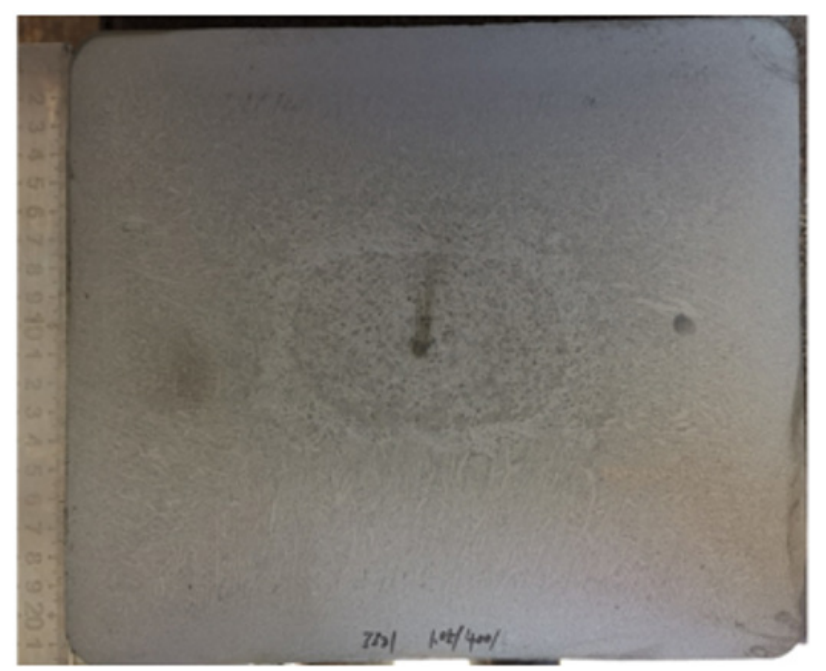

Figure 1: Macro-structure of continuous casting billet under test parameters. 


$$
\delta=K \sqrt{\frac{L}{V}}
$$

Where, $\delta$ is the thickness of the blank shell, unit is $\mathrm{mm}$; $\mathrm{L}$ is the distance between the position of measuring the thickness of the billet shell and the meniscus (unit is $\mathrm{m}$ ); $\mathrm{V}$ is the pulling speed, unit is $\mathrm{m} / \mathrm{min}$; $\mathrm{K}$ is the comprehensive solidification coefficient, the unit is $\mathrm{mm} / \mathrm{min}^{1 / 2}$.

According to the measurement, the position where the white bright band appears at the end of electromagnetic stirring is $80 \mathrm{~mm}$ from the surface of the casting billet, so the thickness of solidified billet shell at the final stirring position can be determined to be $80 \mathrm{~mm}$. By putting the data of final stirring position, drawing speed and solidification shell thickness into Equation 6, it can be concluded that the comprehensive solidification coefficient of the test caster under this cooling intensity is $25.73 \mathrm{~mm} / \mathrm{min}^{1 / 2}$.

\section{References}

1. M Suzuki, Y Yamaoka (2003) Influence of carbon content on solidifying shell growth of carbon steels at the initial stage of solidification. Materials Transactions 44 (5): 836-844.
2. Piszczek KM, Dziarmagowski M, Buczek A, Pioro J (2012) The methods of calculating the solidifying strand shell thickness in a continuous casting machine. Archives of Materials Science and Engineering 57(2): 75-79.

3. H Zhang, W Wang (2017) Mold simulator study of heat transfer phenomenon during the initial solidification in continuous casting mold. Metallurgical and Materials Transactions B 48(4): 793-807.

4. Trindade LB, Nadalon JEA, Contini AC, Barroso RC (2017) Modeling of solidification in continuous casting round billet with mold electromagnetic stirring (M-EMS). Steel Research International 88(4): 1600319.

5. Ha MY, Lee HG, Seong SH (2003) Numerical simulation of threedimensional flow, heat transfer, and solidification of steel in continuous casting mold with electromagnetic brake. Journal of Materials Processing Technology 133(3): 322-339.

6. Sun H, Li L, Cheng X, Qiu W (2015) Reduction in macrosegregation on $380 \mathrm{~mm} \times 490 \mathrm{~mm}$ bloom caster equipped combination M+ F-EMS by optimising casting speed. Ironmaking \& Steelmaking 42(6): 439-449.

7. Li S, Han Z, Zhang J (2020) Numerical Modeling of the macrosegregation improvement in continuous casting blooms by using F-EMS. JOM 72(11): 4117-4126.

For possible submissions Click below: 